\title{
AS1411-Templated Fluorescent Cu Nanomaterial's Synthesis and Its Application to Detecting Melamine
}

\author{
Lu Ga, ${ }^{1}$ Jun Ai $\mathbb{D}{ }^{2}$ and Yong Wang $\mathbb{D}^{3}$ \\ ${ }^{1}$ College of Pharmacy, Inner Mongolia Medical University, Jinchuankaifaqu, Hohhot 010110, China \\ ${ }^{2}$ College of Chemistry and Environmental Science, Inner Mongolia Normal University, 81 Zhaowudalu, Hohhot 010022, China \\ ${ }^{3}$ College of Geographical Science, Inner Mongolia Normal University, 81 Zhaowudalu, Hohhot 010022, China
}

Correspondence should be addressed to Jun Ai; imacaj01@163.com and Yong Wang; wangyonglsx@163.com

Received 2 July 2019; Revised 2 February 2020; Accepted 29 February 2020; Published 20 May 2020

Academic Editor: Marcone A. L. de Oliveira

Copyright ( $92020 \mathrm{Lu} \mathrm{Ga}$ et al. This is an open access article distributed under the Creative Commons Attribution License, which permits unrestricted use, distribution, and reproduction in any medium, provided the original work is properly cited.

\begin{abstract}
Herein, we report a novel approach to AS1411-templated formation of fluorescent copper nanomaterials and their application to melamine detection. Fluorescent copper nanomaterials were formed at room temperature by using AS1411 as a template and ascorbic acid as reductant. However, the fluorescence intensity decreased obviously in the presence of melamine. Under the optimized conditions, the quenching fluorescence intensities of copper nanomaterials showed a good linear relationship with the concentration of melamine in the range of $50 \mu \mathrm{mol} / \mathrm{L}-120 \mu \mathrm{mol} / \mathrm{L}$, and the correlation coefficient was 0.9823 . In addition, the method was successfully applied in the detection of melamine in milk samples. This method was cost-effective and convenient without any labels or complicated operations. Thus, this work successfully develops the capping AS1411 scaffolds of copper nanomaterials detection of melamine.
\end{abstract}

\section{Introduction}

Melamine, chemically known as 2,4,6-triamino-1,3,5-triazine, is rich in terms of nitrogen and heterocyclic organic chemical. Raw materials are mainly used in the production of melamine formaldehyde resin, and this resin is widely used in wood, plastics, paper, textiles, leather, and other industries. Melamine can also be used as flame retardants, water reducing agents, formaldehyde cleaning agents, etc. [1]. Because melamine molecules contain a large number of nitrogen elements, the regular "Kjeldahl method" cannot eliminate the interference of this kind of "pseudoprotein nitrogen" in the detection of protein content in food or feed, so it is illegal.

To reduce costs, the nonfood chemicals are added to milk, milk powder, and feed to increase protein content in their products. In October 2008, China formulated a management limit for melamine in dairy products and a limit for melamine in infant formula milk powder. The limit value of melamine in other foods containing more than $15 \%$ milk is $1 \mathrm{mg} / \mathrm{kg}$ and $2.5 \mathrm{mg} / \mathrm{kg}$. At present, the main detection methods of melamine are gas chromatography-mass spectrometry (GC-MS) [2, 3], high-performance liquid chromatography (HPLC) [4-6], and liquid chromatography-mass spectrometry (LC-MS) [7-9] as they have high accuracy, but the sample pretreatment is complex, the equipment is expensive, and cost of testing is high. In recent years, enzyme-linked immunosorbent assay [10-12] and colloidal immunochromatographic strip $[13,14]$ have been used for the detection of melamine.

However, the sensitivity is not high enough or the specificity is not strong enough. The molecular structure of melamine has been reasonably repaired in this study. Two melamine derivatives were synthesized and linked with bovine serum albumin and chicken egg albumin, respectively, to produce immunogen and coated antigen. A monoclonal antibody against melamine was prepared by the hybridoma antibody preparation technique. Based on the antibody, a method, colloidal gold immunochromatographic assay, was established for the determination of melamine in milk, milk powder, and feed..

The templates used in the synthesis process include treeshaped macromolecules, polymers, small mercaptoid 
molecules, proteins, sugar molecules, polypeptides, and DNA [15]. It is very important to select the appropriate template for the study of its fluorescence properties. In this experiment, DNA was used as the template to synthesize nanoparticles. DNA sequence can be designed, has good biocompatibility and unique biological recognition, and are often widely used as synthetic template [16-20]; specific sequences of DNA template can adjust the optical properties of metal nanoparticles and electronic structure of the DNA sequence, and the combination of nanotechnology in every field has a widespread application prospect and research value.

DNA-Cu NPs can be prepared by adding $\mathrm{Cu}^{2+}$, DNA and reductants in a certain proportion. The reductants used in this experiment are ascorbic acid, DNA as the template, and copper nitrate as the raw material to synthesize DNA-Cu NPs. For DNA, the template preparation method of copper nano materials can be divided into two categories: the first category is dsDNA templates; in 2010, Mokhir et al. [21] reported for the first time in a random sequence dsDNA for template synthesis of $\mathrm{Cu}$ NPs and in 2015, Ouyang et al. [22] with repeated AT specific sequences of bases dsDNA-CuNPs synthesis. The second type is based on ssDNA. In 2013, Wang et al. [23] reported that polyTssDNA could also synthesize CuNPs, which is easier to operate and has more fluorescence.

The size of DNA-Cu NPs is small, the toxicity is low, the optical stability is good [24], and it is easy to be regulated [25]. DNA is a genetic material of the body that has been extensively studied in labeling and imaging.

\section{Materials and Methods}

2.1. Instruments and Reagents. F-4600 fluorescence spectrophotometer (Hitachi Hitachi High-tech Company); JEM2100F transmission electron microscope (Japan Electronics Corporation). $\mathrm{Cu} \quad\left(\mathrm{NO}_{3}\right)_{2} . \quad 3 \mathrm{H}_{2} \mathrm{O} \quad$ (Tianjin Fengshuan Chemical Reagent Technology Co., Ltd.) NaCl; KCl (Tianjin Beilian Fine Chemicals Development Co., Ltd.); sodium borohydride (AF granules, 10-40 mesh, 98\%, SigmaAldrich); and all chemicals of analytical grade were used as received without further purification. The oligodeoxynucleotides used in the present study were AS1411, an antiproliferative G-rich oligodeoxynucleotide (GRO) whose sequence is $5^{\prime}$-d(GGTGGTGGTGGTTGTGG TGGTGGTGG)-3'. The AS1411 aptamer was synthesized by Shanghai Sangon Biotechnology Co., Ltd. (Shanghai, China). They are all configured with ultrapure water (a resistance of about $18.25 \mathrm{M} \Omega$ ).

\subsection{DNA Synthesized Copper Nanomaterials. The DNA} sequence was centrifuged for $15 \mathrm{~min}$ at a rotational speed of $5000 \mathrm{RPM}$, and then the buffer solution was added to mix well and then heated for $1 \mathrm{~h}$ in a water bath of $95^{\circ} \mathrm{C}$ for natural annealing treatment.

DNA (including $10 \mu \mathrm{M}, 50$ (including L) was mixed in PBS buffer solution ( $\mathrm{pH}=7.4$, (including $250 \mu \mathrm{L}$ ), ascorbic acid was added $(80 \mathrm{mM}, 80$ (including L) and fully mixed, and then it was added in $(0.8 \mathrm{mM}$, including $100 \mu \mathrm{L}) \mathrm{Cu}$
$\left(\mathrm{NO}_{3}\right)_{2}$ solution in a dark environment under the condition of the hatch a day.

2.3. The Detection of Melamine in Copper Nanoparticles. The DNA $(10 \mu \mathrm{M}, 50 \mu \mathrm{L})$ was added to the PBS buffer solution $(\mathrm{pH}=7.4,250 \mu \mathrm{L})$ and mixed evenly, mixed with ascorbic acid $(80 \mathrm{mM}, 100 \mathrm{~L})$, and then $\mathrm{Cu}^{2+}(0.8 \mathrm{~mm}$, $100 \mu \mathrm{L}$ ) was added to incubate at room temperature. The fluorescence spectrometers were used for the fluorescence test with different concentrations of melamine $(50 \mu \mathrm{M}$, $60 \mu \mathrm{M}, 70 \mu \mathrm{M}, 80 \mu \mathrm{M}, 90 \mu \mathrm{M}, 100 \mu \mathrm{M}, 110 \mu \mathrm{M}$, and $120 \mu \mathrm{M})$.

\section{Results and Discussion}

The excitation wavelength and emission wavelength of DNA-Cu NPs can be obtained by using the fluorescence spectrometer, which are $280 \mathrm{~nm}$ and $390 \mathrm{~nm}$ (Figure 1), and the fluorescence intensity is high.

The morphology and size of DNA-Cu NPs were tested by transmission electron microscopy, and the DNA-Cu NPs was distributed evenly with a smaller size of about $5 \mathrm{~nm}$ and presented a spherical shape. The DNA-Cu NPs synthesized in this experiment is a crystal with a lattice spacing of $0.2479 \mathrm{~nm}$ (Figure 2).

In the optimization experiments, this experiment studied the template agent (DNA) concentration, reducing agent (ascorbic acid) and cupric nitrate $\left(\mathrm{Cu}\left(\mathrm{NO}_{3}\right)_{2}\right)$ volume ratio, and different environment affect the performance of DNA-Cu NPs fluorescence. By Figure 3, as can be seen, the concentration of DNA on the properties of DNA-CuNPs fluorescence effect is very weak, in line with "the molarity minimization, of minimum usage, simple, and quick," and the purpose of this experiment is to select the molar concentration of 10 (including the DNA sequence of $\mathrm{M}$ ). In this experiment, the volume ratio of ascorbic acid and $\mathrm{Cu}\left(\mathrm{NO}_{3}\right)_{2}$ was $1: 1$. In Figure 3(b), the volume of $\mathrm{Cu}\left(\mathrm{NO}_{3}\right)_{2}$ is $200 \mu \mathrm{L}$, and the fluorescence intensity of DNA-CuNPs is stronger. Therefore, the volume of ascorbic acid and copper nitrate used in the experiment was $200 \mu \mathrm{L}$. In this experiment, the effect of reaction environment on the fluorescence properties of DNA-CuNPs was studied. Under the conditions of normal temperature and ice bath, the fluorescence intensity of the reaction environment was not significant (Figure 3(c)). Therefore, for the simple and rapid preparation of DNA-CuNPs, we chose room temperature. In addition, we further studied the template agent and reducing agent on the synthesis of nanomaterials and the effects of copper, as shown in Figure 3(d), which shows that in the absence of template agent, reducing agent, and either one of the copper nitrate, copper can form nanomaterials. This further confirms the work of DNA and ascorbic acid in this study.

This experiment studied the preparation of DNA-Cu NPs to detect melamine, and using the method of internal additive, we used the prepared DNA-Cu NPs to detect the different concentrations of melamine $(50 \mu \mathrm{M}, 60 \mu \mathrm{M}, 70 \mu \mathrm{M}$, $80 \mu \mathrm{M}, 90 \mu \mathrm{M}, 100 \mu \mathrm{M}, 110 \mu \mathrm{M}$, and $120 \mu \mathrm{M})$. It can be concluded from Figure 4 that with the increase of melamine 


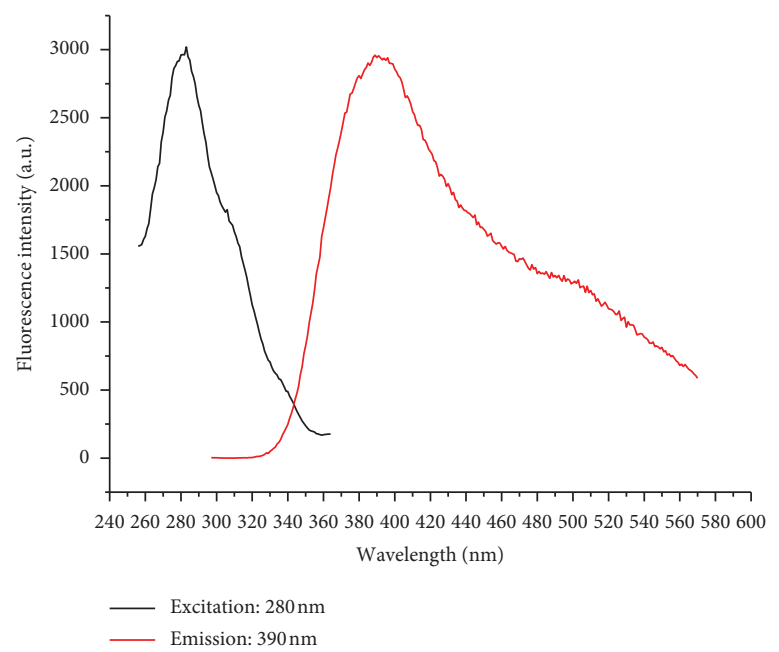

Figure 1: Fluorescence spectra of DNA-Cu NPs.

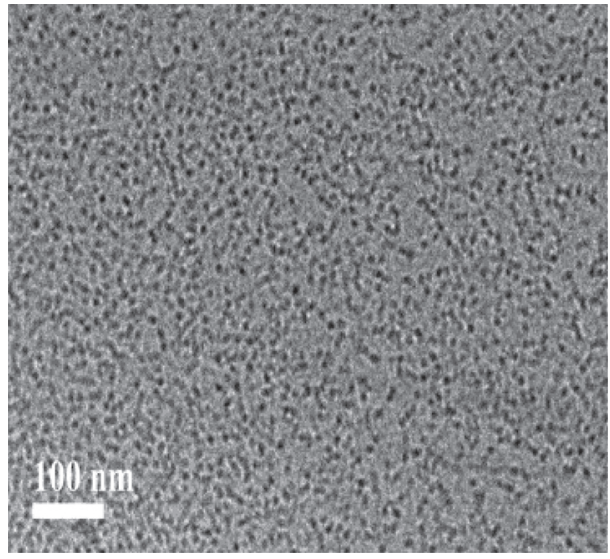

(a)

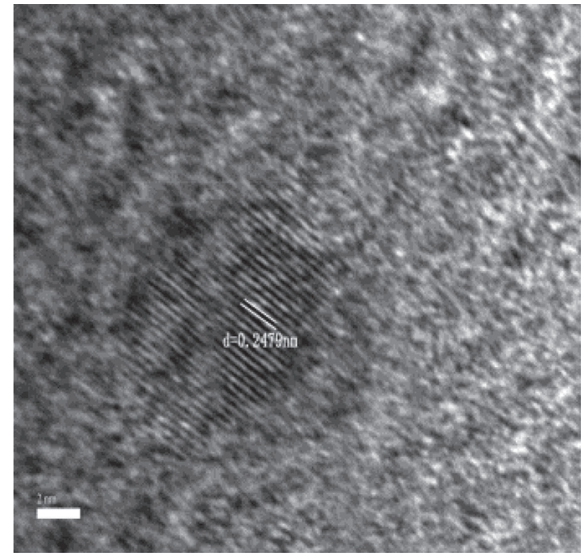

(b)

FIgURE 2: TEM image of DNA-Cu NPs.

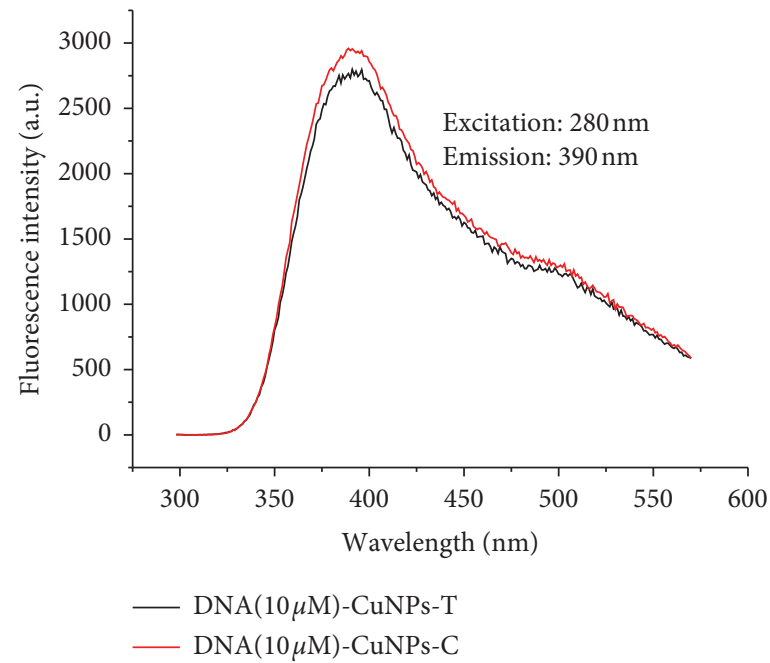

(a)

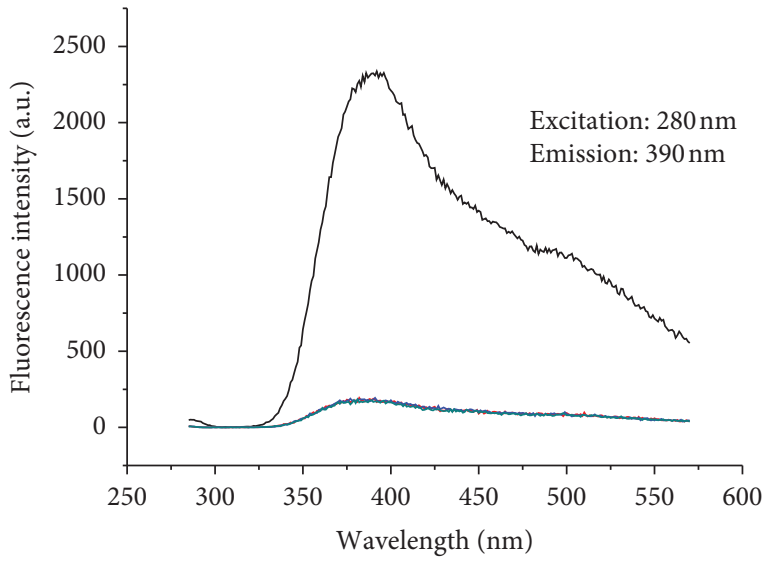

$\begin{array}{ll}- \text { DNA-CuNPs } & \mathrm{Cu}\left(\mathrm{NO}_{3}\right)_{2}+\text { ascorbic } \\ \text { DNA + ascorbic } & \text { acid } \\ \text { acid } & -\mathrm{DNA}+\mathrm{Cu}\left(\mathrm{NO}_{3}\right)_{2}\end{array}$

(b)

Figure 3: Continued. 


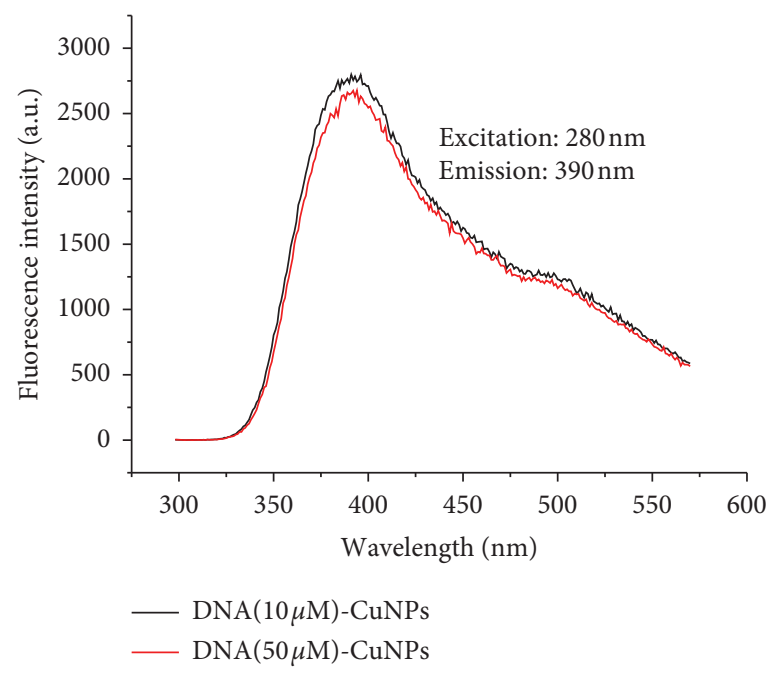

(c)

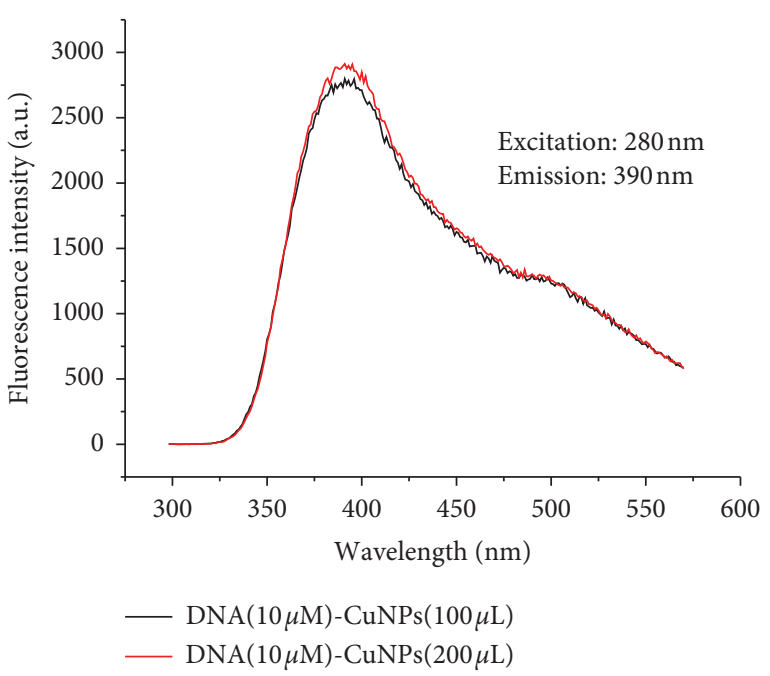

(d)

Figure 3: Fluorescence spectra of (a) the influence of DNA to DNA-Cu NPs, (b) the effect of volume to DNA-Cu NPs, (c) effect of reaction environment to DNA-Cu NPs, and (d) the influence of template and reducing agent to copper nanomaterials.

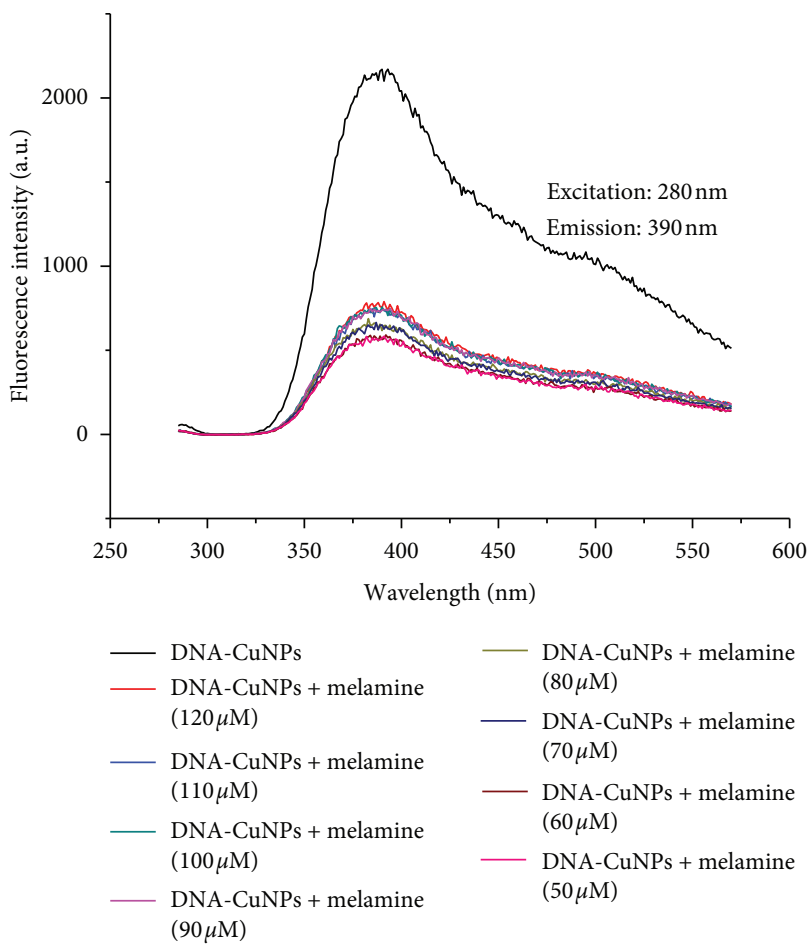

(a)

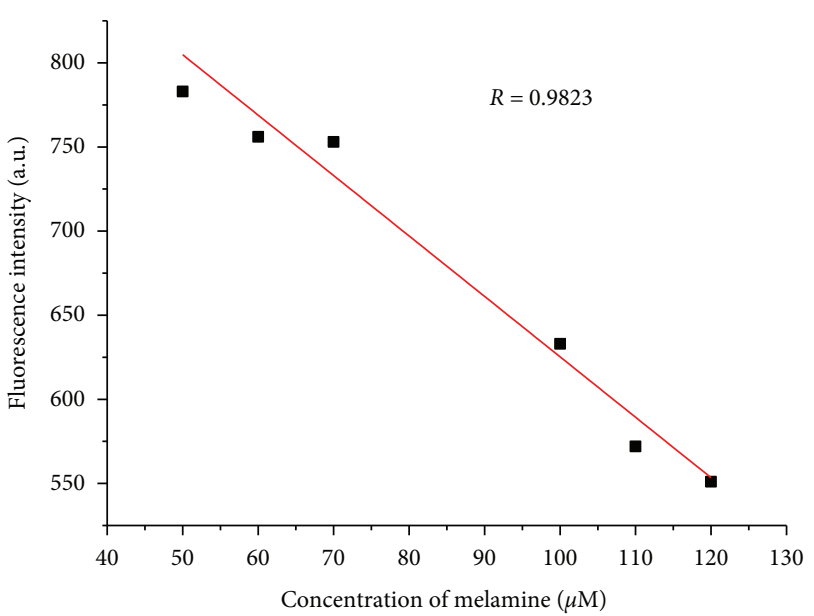

(b)

FIgURE 4: Fluorescence spectra of detection of melamine by DNA-Cu NPs.

concentration, the fluorescence intensity decreased and the relationship of negative correlation was presented. Moreover, the concentration of melamine showed a good linear relationship with fluorescence intensity, and its linear equation was $F=-3.59\left[\mathrm{C}_{3} \mathrm{H}_{6} \mathrm{~N}_{6}\right] / \mathrm{M}+894.42(R=0.91)$. This kind of phenomenon is because with the industrial chemical melamine in DNA-Cu NPs and $\mathrm{Cu}^{2+}$ with melamine in coordination reaction, that is unfavorable to $\mathrm{Cu}^{2+}$ to $\mathrm{CuO}$, preventing the formation of DNA-CuNPs, and during the synthesis of DNA-Cu NPs, fluorescence intensity is reduced greatly. The decrease of fluorescence intensity is negatively correlated with the concentration of melamine, which can 
realize the detection of melamine by DNA-Cu NPs. Therefore, this method provides a way for the analysis and detection of melamine and has potential application value in the field of food safety analysis.

\section{Conclusion}

In this paper, we mainly studied the synthesis of copper nanomaterials using DNA sequence as the template and ascorbic acid and sodium borohydride as reductants. The effects of templates and reductants on the synthesis of nanomaterials were also discussed. The copper nanomaterials synthesized in this study have higher fluorescence intensity and smaller particles with clear crystal lattice. In addition, the linear relationship between the concentration of melamine and the fluorescence intensity of DNA-Cu NPs was also studied. Therefore, this method provides a way for the analysis and detection of melamine and has potential application value in the field of food safety analysis.

\section{Data Availability}

The data used to support the findings of this study are available from the corresponding author upon request.

\section{Conflicts of Interest}

The authors declare that they have no conflicts of interest.

\section{Acknowledgments}

This work was supported by the National Science Foundation of China (Grant no. 21864020), the Natural Science Foundation of Inner Mongolia (Grant no. 2018MS02012), Collaborative Innovation Center for Water Environmental Security of Inner Mongolia Autonomous Region, China, (Grant no. XTCX003), and the Inner Mongolia innovation guide project and Research Project of Higher School, Department of Education of Inner Mongolia Autonomous Region (Grant no. NJZC16047).

\section{Supplementary Materials}

Figure S1: the selectivity of the method for melamine detection. Table S1: comparison of different methods for the detection of melamine. Table S2: results of the determination of the melamine in milk samples. (Supplementary Materials)

\section{References}

[1] F. Andersen, "Final Report on the Safety Assessment of Melamine/Formaldehyde Resin," Journal of the American College of Toxicology, vol. 14, no. 5, p. 373, 1995.

[2] X.-M. Xu, Y.-P. Ren, Y. Zhu et al., "Direct determination of melamine in dairy products by gas chromatography/mass spectrometry with coupled column separation," Analytica Chimica Acta, vol. 650, no. 1, pp. 39-43, 2009.

[3] X. Zhu, S. Wang, Q. Liu, Q. Xu, S. Xu, and H. Chen, "Determination of residues of cyromazine and its metabolite, melamine, in animal-derived food by gas chromatography-mass spectrometry with derivatization," Journal of
Agricultural and Food Chemistry, vol. 57, no. 23, pp. 1107511080, 2009.

[4] Y.-S. Li, Q.-Q. Liang, Y.-Q. Hou, and H.-X. Li, "A flow-injection on-line solid phase extraction, enrichment system for determination of melamine in milk products based on high performance liquid chromatography," Chinese Journal of Analytical Chemistry (Chinese Version), vol. 40, no. 2, p. 298, 2012.

[5] G. Venkatasami and J. R. Sowa, "A rapid, acetonitrile-free, HPLC method for determination of melamine in infant formula," Analytica Chimica Acta, vol. 665, no. 2, pp. 227230, 2010.

[6] H. Sun, L. Wang, L. Ai, S. Liang, and H. Wu, "A sensitive and validated method for determination of melamine residue in liquid milk by reversed phase high-performance liquid chromatography with solid-phase extraction," Food Control, vol. 21, no. 5, pp. 686-691, 2010.

[7] A. J. Li, D. H. Zhang, S. M. Ma, M. Li, X. Z. Zhang, and T. L. Yao, Chinese Journal of Analytical Chemistry, vol. 36, p. 699, 2008.

[8] Y.-T. Wu, C.-M. Huang, C.-C. Lin et al., "Oral bioavailability, urinary excretion and organ distribution of melamine in Sprague-Dawley rats by high-performance liquid chromatography with tandem mass spectrometry," Journal of Agricultural and Food Chemistry, vol. 58, no. 1, pp. 108-111, 2010.

[9] F. Huang, X. L. Huang, H. Q. Wu, X. Deng, X. S. Lin, and Z. X. Zhu, Journal of Instrumental, Analysis, vol. 27, p. 313, 2008.

[10] W. Yin, J. Liu, T. Zhang et al., "Preparation of monoclonal antibody for melamine and development of an indirect competitive ELISA for melamine detection in raw milk, milk powder, and animal feeds," Journal of Agricultural and Food Chemistry, vol. 58, no. 14, pp. 8152-8157, 2010.

[11] J. Liu, Y. Zhong, J. Liu, H. Zhang, J. Xi, and J. Wang, “An enzyme linked immunosorbent assay for the determination of cyromazine and melamine residues in animal muscle tissues," Food Control, vol. 21, no. 11, pp. 1482-1487, 2010.

[12] H. Lei, Y. Shen, L. Song et al., "Hapten synthesis and antibody production for the development of a melamine immunoassay," Analytica Chimica Acta, vol. 665, no. 1, pp. 84-90, 2010.

[13] X. Li, P. Luo, S. Tang et al., "Development of an immunochromatographic strip test for rapid detection of melamine in raw milk, milk products and animal feed," Journal of Agricultural and Food Chemistry, vol. 59, no. 11, pp. 6064-6070, 2011.

[14] F. Sun, L. Liu, W. Ma, C. Xu, L. Wang, and H. Kuang, "Rapid on-site determination of melamine in raw milk by an immunochromatographic strip," International Journal of Food Science \& Technology, vol. 47, no. 7, pp. 1505-1510, 2012.

[15] Y. Zhang, Preparation and Application of Precious Metal Nanoparticles Guided by DNA Template, Tianjin University, Tianjin, China, 2010.

[16] Y. Li, Fluorescence Biosensor Technology Based on DNA Silver Nanoclusters and Antibacterial Properties of Silver Nanoparticles, Hunan University, Changsha, China, 2016.

[17] H.-B. Wang, H.-D. Zhang, Y. Chen, and Y.-M. Liu, "A fluorescent biosensor for protein detection based on poly(thymine)-templated copper nanoparticles and terminal protection of small molecule-linked DNA," Biosensors and Bioelectronics, vol. 74, pp. 581-586, 2015.

[18] H.-B. Wang, H.-D. Zhang, Y. Chen, K.-J. Huang, and Y.-M. Liu, "A label-free and ultrasensitive fluorescent sensor for dopamine detection based on double-stranded DNA templated copper nanoparticles," Sensors and Actuators B: Chemical, vol. 220, pp. 146-153, 2015.

[19] H.-B. Wang, Y. Chen, Y. Li, and Y.-M. Liu, "Blocking the formation of fluorescent poly(thymine)-templated copper 
nanoparticles for label-free and sensitive detection of kojic acid in foodstuffs," Analytical Methods, vol. 8, no. 47, pp. 8322-8328, 2016.

[20] H.-B. Wang, H.-D. Zhang, Y. Chen, and Y.-M. Liu, "Inhibition of double-stranded DNA templated copper nanoparticles as label-free fluorescent sensors for l-histidine detection," New Journal of Chemistry, vol. 39, no. 11, pp. 8896-8900, 2015.

[21] A. Rotaru, S. Dutta, E. Jentzsch, K. Gothelf, and A. Mokhir, "Selective dsDNA-templated formation of copper nanoparticles in solution," Angewandte Chemie International Edition, vol. 49, no. 33, pp. 5665-5667, 2010.

[22] Q. Song, Y. Shi, D. He, S. Xu, and J. Ouyang, "Sequencedependent dsDNA-templated formation of fluorescent copper nanoparticles," Chemistry-A European Journal, vol. 21, no. 6, pp. 2417-2422, 2015.

[23] K. Wang, F. Xu, T. Qing, X. Yang et al., "Poly(thymine)templated selective formation of fluorescent copper nanoparticles," Angewandte Chemie International Edition, vol. 52, no. 37, pp. 9719-9722, 2013.

[24] H. Zhang, A new method of non-labeled biosensor based on DNA template fluorescent copper nanoparticles, Xinyang Normal University, Xinyang, China, 2016.

[25] F. Xu, Fluorescence Biochemical Sensing Based on Copper Nanoparticles and Graphene Materials and Its Application, Hunan University, Changsha, China, 2015. 